University of Nebraska - Lincoln

DigitalCommons@University of Nebraska - Lincoln

2010

\title{
Locus of Control, Sources of Motivation, and Mental Boundaries as Antecedents of Leader-Member Exchange Quality
}

John E. Barbuto Jr.

University of Nebraska-Lincoln

Dayna Finch Weltmer

Creighton University

Lisa A. Pennisi

University of Nebraska-Lincoln, Ipennisi2@unl.edu

Follow this and additional works at: https://digitalcommons.unl.edu/natrespapers

Part of the Natural Resources and Conservation Commons, Natural Resources Management and Policy Commons, and the Other Environmental Sciences Commons

Barbuto, John E. Jr.; Weltmer, Dayna Finch; and Pennisi, Lisa A., "Locus of Control, Sources of Motivation, and Mental Boundaries as Antecedents of Leader-Member Exchange Quality" (2010). Papers in Natural Resources. 964.

https://digitalcommons.unl.edu/natrespapers/964

This Article is brought to you for free and open access by the Natural Resources, School of at DigitalCommons@University of Nebraska - Lincoln. It has been accepted for inclusion in Papers in Natural Resources by an authorized administrator of DigitalCommons@University of Nebraska - Lincoln. 


\section{LOCUS OF CONTROL, SOURCES OF MOTIVATION, AND MENTAL BOUNDARIES AS ANTECEDENTS OF LEADER-MEMBER EXCHANGE QUALITY ${ }^{1}$}

JOHN E. BARBUTO, JR.

University of Nebraska-Lincoln
DAYNA FINCH WELTMER

Creighton University

LISA A. PENNISI

University of Nebraska-Lincoln

Summary. - In this study were examined leaders' and members' scores on locus of control, sources of motivation, and mental boundaries to predict the quality of leader-member exchanges. 80 elected officials and their 388 direct reports were sampled in a field study. Analysis indicated followers' scores on locus of control, leaders' scores of self-concept internal motivation, leaders' scores on locus of control, and followers' rated goal-internalization motivation were positively related to leader-member exchanges. Implications and directions for research are discussed.

Research on the antecedents of leader-member exchange has been extensive over the past 25 years (Graen \& Uhl-Bien, 1995). Studies testing the antecedents of leader-member exchange have included sex of participants (Tsui \& O'Reilly, 1989; Wayne, Liden, \& Sparrowe, 1994), attitude and personality similarity (Dienesch \& Liden, 1986; Wayne \& Ferris 1990; Liden, Wayne, \& Stilwell, 1993; Phillips \& Bedeian, 1994), work values (Steiner \& Dobbins, 1989), liking (Dockery \& Steiner, 1990; Liden, et al., 1993), liking from the members' perspectives (Liden, et al., 1993), personality (Burns, 1995), locus of control, least preferred coworker, power, and achievement needs to predict leader-member exchange (McClane, 1991) and locus of control (Kinicki \& Vecchio, 1994; Martin, Thomas, Charles, Epitropaki, \& McNamara, 2005). These studies have contributed to an expansive body of knowledge for understanding the origin of leader-member exchange.

Graen and Uhl-Bien (1995) called for continued research, suggesting that antecedents in this area have just begun to be specified. To date, no studies have examined such dispositional variables as sources of motivation and mental boundaries. This is of concern because motivation has been used to predict many leadership phenomena (Barbuto, 1998; Barbuto \& Scholl, 1999; Barbuto, Fritz, \& Marx, 2000). Examining these variables in a predictive framework is a necessary step to discover antecedents of leader-member exchange.

${ }^{1}$ Address correspondence to J. E. Barbuto, Jr., Leadership Studies, University of NebraskaLincoln, Lincoln, NE 68583-0709 or e-mail (jbarbuto@unl.edu). 


\section{Leader-Member Exchange}

Leader-Member Exchange refers to the unique relationship quality which leaders develop with subordinates. It was originally termed Vertical Dyad Linkage (Dansereau, Cashman, \& Graen, 1973) but was later renamed leader-member exchange (Graen, Novak, \& Sommerkamp, 1982). Leader-member exchange concerns the extent to which leaders and followers have developed a trusting, autonomous, and mutually beneficial relationship (Graen \& Uhl-Bien, 1995). Different factors may change the quality of developed leader-member exchanges so it is important that this approach must reflect attention to unique qualities each member of the dyad brings to the relationship. In this study the link between leaders' locus of control and leader-member exchange in addition to effects of followers' locus of control on this relationship were tested as well as leaders' mental boundaries and sources of motivation as predictors of leadermember exchange.

\section{Locus of Control}

Researchers have stated that locus of control is an important construct in explaining behavior in the organizational settings. Rotter (1966) noted that subordinates' internal-external locus of control is one variable of possible importance in the role-making process. Both Spector (1982) and Hawk (1989) suggested that an appropriate supervisory style depends on subordinates' locus of control. Kinicki and Vecchio (1994) also regarded employees' locus of control as a suspected antecedent of dyadic quality and reported significant correlation between leader-member exchange and employees' locus of control, which was also correlated with organizational commitment. Rotter (1966) argued that when a person perceives reinforcement to be contingent on behavior, an internal locus of control is operational, whereas when such reinforcements are attributed to chance, luck, powerful others, or the complexity of the situation, then external locus of control is evident.

Individuals with an internal locus of control ascribe control of events to themselves, while those having external locus of control attribute control to outside forces. Persons who score as internal relative to those whose scores indicate an external view have been reported to show higher work motivation, effort, performance, job satisfaction, larger starting salaries, and larger salary increases (Spector, 1982; Nystrom, 1983). Therefore, those scoring high on internal locus of control are likely to control outcomes via initiative-based rather than compliance-based behaviors.

In the leader-member exchange model, such leader-to-follower negotiation is characteristic of high quality exchanges (Phillips \& Bedeian, 1994). Johnson, Luthans, and Hennessey (1984) found that locus of control accounted for a small amount of the variance of the leaders' influence be- 
haviors, as was the case with the previous research. Phares (1973) suggested that, although little variance was observed, the consistency across studies was evidence of the robustness of the construct. Johnson, et al. (1984) stated that subordinates' satisfaction was higher when supervisors scored as internal in locus of control. Howell and Avolio (1993) found internal locus of control to be positively related to ratings of transformational leadership behavior. Deluga (1992) and Howell and Hall-Merenda (1999) explicitly tested the hypothesis that high quality leader-member exchange was associated with transformational leadership. Gerstner and Day (1997) emphasized that the behavioral manifestations of high leader-member exchange are categorically similar to those practiced in transformational leadership. Locus of control then represents a key personal characteristic, which should share a positive relationship with leader-member exchange.

Hypothesis 1: Scores on internal locus of control of leaders will be positively related to leader-member exchange.

\section{Mental Boundaries}

Mental boundaries have been described in the literature since Sigmund Freud's early work on hierarchical ordering of neurological structures (Freud, 1933), but efforts to measure these boundaries empirically have been scant until recently. Mental boundaries, first conceptualized and measured by Hartmann (1991), are psychological constructs relating to how individuals view themselves and the world around them. Hartmann (1991) developed 12 categories of mental boundaries, each having a wide range of application from dream patterns, interpersonal relationships, opinions about nations and people, to opinions about organizations and groups.

Mental boundaries evolved from Freud's idea that the conscious and unconscious aspects of mind form a distinct and measurable construct (Houran, Thalbourne, \& Hartmann, 2003). Hartmann, Rosen, and Rand (1998) described the 138-item boundary questionnaire as a measure of the extent of separateness versus connectedness across mental functions.

Hartmann (1991) described individuals with thick mental boundaries as placing less value on relationships and more value on structure. This stems from the personal distance necessitated by thick mental boundaries. It follows that individuals more concerned with categorization and distance may resort to increased use of aggressive, coercive, or socially unacceptable actions. In addition, previous perceptions of effective leadership have been associated with masculine and dominant behaviors (Lord, DeVader, \& Alliger, 1986).

Hartmann (1991) described individuals with thin mental boundaries as those who become easily involved with others, even losing their 
identity in the process. Individuals with thin mental boundaries are consequently more likely to favor the development of strong interpersonal bonds and willingly relinquish interpersonal space. Followers with thick mental boundaries are predisposed to use hard influence, prefer structure and order in their environment, and do not value relationships as highly. They would not naturally use "soft" tactics to gain compliance because soft tactics require mutual vulnerability and fluidity of roles.

If leaders and followers share similar mental boundaries, they are classified as congruent. When mental boundaries are categorically different, they may be classified as incongruent. In situations in which leaders and followers have thick mental-boundary congruence, leaders are likely to exhibit a mutual respect for each other's personal space and formalities. Individuals with thick mental boundaries are sensitive to demanding special favors or invading the personal space of others. As a result, they are inclined to adopt soft influence strategies, which reinforce mutual respect, courtesy, and professionalism.

In situations when the leader and follower have thin mental-boundary congruence, leaders are likely to suspend all the formalities and procedures in influence processes. As a result, leaders may demand special favors and violate the interpersonal space of others. In these instances, with thin mental-boundary congruence, followers may not mind their space being invaded, which propagates the informality.

For interpersonal relationships, thin boundaries reflect interactions which are less clearly defined and thicker boundaries reflect relationship expectations which are predictably defined. In terms of diversity, individuals with thicker boundaries typically are drawn to people who are personally similar racially, religiously, or organizationally. Those with thinner boundaries tend to mix with people who are different from them. Barbuto and Plummer (1998) compared Hartmann's thick and thin boundaries with Jung's psychological types (1923/1971) and found that the boundary questionnaire measures a personality dimension unique from those measured on the Myers-Briggs Personality Type Indicator. It was expected that mental boundaries would have a positive relation with leader-member exchanges.

Hypothesis 2a: Leaders' thin mental boundaries will be positively related to leader-member exchange.

Hypothesis $2 \mathrm{~b}$ : Leaders' thin mental boundaries will be negatively related to leader-member exchange variance among employees.

\section{Source of Motivation}

Motivation has been studied from many perspectives, including need-based hierarchical models (Maslow, 1954; Alderfer, 1969), trichotomy of needs (McClelland, 1961), motivation and hygiene factors (Herz- 
berg, 1968), and intrinsic or extrinsic dichotomies (Deci, 1975). Scholars have argued that although there are a variety of motivation theories, there is neither a unifying theme nor research support (Locke \& Henne, 1986). More recent articulations have proposed an integrative content-based model of work motivation (Leonard, Beauvais, \& Scholl, 1999). Leonard, et al. (1999) synthesized current theories and proposed a meta-theory of work motivation based on five sources. This typology accounts for the diversity of motives in the work place with five sources, namely, intrinsic process, instrumental, self-concept external, self-concept internal, and goal internalization.

Intrinsic process motivation. - Intrinsic process motivation is evident when workers are motivated to engage in an activity because they enjoy doing it. People are motivated by the work because it is enjoyable. Intrinsic process motivation is characterized by an enjoyment in the work (Barbuto, Fritz, \& Marx, 2002). Workers' fun in their work setting may inspire those classified as followers to emulate the leaders' behavior and incorporate enjoyment and pleasure with work (Avolio, Waldman, \& Einstein, 1988).

Hypothesis 3: Leaders' intrinsic process motivation will be positively related to leader-member exchange.

Instrumental motivation. - Instrumental motivation is derived from tangible outcomes and is evident when individuals engage in behaviors to receive material gains such as pay, promotions, and bonuses. Instrumentally motivated leaders see the value in a reward system for employees (Barbuto, et al., 2002). Similarly, transactional leaders work within a system of reward and punishment for employees (Bass, 1990). Scholars have drawn many behavioral comparisons between transactional leadership and low leader-member exchange so one might expect leaders high in instrumental motivation would likely have low quality of leader-member exchanges (Gerstner \& Day, 1997).

Hypothesis 4: Leaders' instrumental motivation will be negatively related to leader-member exchange.

Self-concept external motivation.-Self-concept external motivation is derived from a strong desire to solicit and receive positive affirmation of traits, competencies, and values (Leonard, et al., 1999). If individuals perform behaviors to garner affirmation from others, then self-concept external motivation may be said to occur.

Prior research has shown a negative relationship between self-concept external motivation with transformational leadership (Barbuto, et al., 2000). It was expected that self-concept external motivation would share many characteristics with transactional leadership as well as charismatic leadership. Since leader-member exchange and transformational lead- 
ership have been described as behaviorally similar, one may expect that leaders with high self-concept external motivation would likely have low quality leader-member exchange processes (Gerstner \& Day, 1997).

Hypothesis 5: Leaders' self-concept external motivation will be negatively related to leader-member exchange.

Self-concept internal motivation.-Self-concept internal motivation is derived from internal standards of achievement which become the basis for self-evaluation of traits, competencies, and values (Leonard, et al., 1999). If individuals engage in a behavior which reinforces their self image, then self-concept internal motivation is evident. A leader who is motivated by self-concept internal is likely to value individual members and the unique characteristics and strengths that each brings (Barbuto \& Scholl, 1999). The leader will inspire followers to provide unique contributions in accord with their personal goals as well as the goals of the leader. It was expected that self concept internal will be positively related to leader-member exchange.

Hypothesis 6: Leaders' self-concept internal motivation will be positively related to leader-member exchange.

Goal-internalization motivation.-Goal-internalization motivation is derived from individuals' need to believe in the purpose of activities before being motivated (Leonard, et al., 1999). If individuals develop a sense of mission in work and have an internal value-based desire to see the mission succeed, then goal-internalization motivation occurs (Barbuto \& Scholl, 1999). Such leaders inspired by goal-internalization motivation are likely to value those individuals who have a strong sense of their ideals and beliefs (Barbuto \& Scholl, 1999). The leader will inspire followers to trust the goals of the organization and to work towards achieving these goals. Barbuto, et al. (2000) reported significant relations between leaders' goal internalization and their use of transformational leadership behaviors. Thus, a relationship was expected between goal internalization and the quality of leader-member exchanges.

Hypothesis 7: Leaders' goal-internalization motivation will be positively related to leader-member exchange.

Intrinsic and extrinsic motivation. - For the purpose of this study, the five sources of work motivation were further divided into two categories, intrinsic or internal (Deci, 1975; Staw, 1976), comprised of intrinsic process, self-concept-internal and goal internalization, and extrinsic/external (Deci, 1975; Staw, 1976), comprised of instrumental and self-concept external. Intrinsic or internal motivation embodies the person and emotions. It encompasses fun, trust, and self-worth, each of which were derived from internal influences. These qualities are similar to those needed for transformational behaviors (Burns, 1978; Bass, 1985, 1990). An extrinsic 
or external combined process really derives from the surroundings of the person (Barbuto \& Scholl, 1998). Instrumental work motivation and selfconcept external motivation combine to form what is classically understood as extrinsic motivation. People influenced by an extrinsic or external process are motivated by prestige, rewards, and status, perhaps more suitable to transactional and charismatic leadership (Hater \& Bass, 1988; Bass, 1990).

Hypothesis 8: Leaders' intrinsic or internal motivation will be positively related to leader-member exchange.

Hypothesis 9: Leaders' extrinsic or external motivation will be negatively related to leader-member exchange.

\section{Method}

\section{Subjects}

The participants were 80 elected community leaders and 388 raters in the midwestern USA. Leaders attended a leadership development workshop for elected officials and were members of a statewide professional organization which sponsored the event. Leaders served as treasurers in their respective counties and were elected by the county population. Their average age was $51 \mathrm{yr}$. Fifty percent had earned a bachelor's degree, while $20 \%$ had earned a master's degree or higher. Sixty-five percent of the leaders were women. Raters were colleagues or employees of the leaders and reported an average age of $46 \mathrm{yr}$. Of these raters, $42 \%$ had earned a bachelor's degree, while fewer than $10 \%$ had earned a master's degree or higher. Of these raters, $53 \%$ were women.

Tests

LMX-7 was the measure used for leader-member exchange. It is a 7-item Likert-type scale using anchors of 1: Strongly disagree and 5: Strongly agree. This measure has been used extensively in research and seems to be regarded as the gold standard measure (Gerstner \& Day, 1997).

Sources of work motivation were measured using the Motivation Sources Inventory (Barbuto, 2004), a 30-item inventory of five subscales with six questions each; coefficients $\alpha$ ranged from .68 to .84 (Barbuto \& Scholl, 1998). In addition to alpha, Revelle's beta was computed in this study to estimate reliability. Beta represents the proportion of variance due to one common factor and is essentially the worst split-half reliability (Zinbarg, Revelle, Yovel, \& Li, 2005). Therefore, Beta is a more conservative estimate than alpha. Since it has been argued that alpha is not a good measure of unidimensionality and that estimates such as Beta should be used when the measure is multidimensional (Revelle \& Zinbarg, 2009), both alpha and beta are reported here. Motivation Sources Inventory (Barbuto, 2004) questions were formatted in Likert-type scales 
ranging from 0: Completely disagree to 6: Completely agree. In this study, the five subscales - intrinsic process ("I prefer to do things that are fun"; $\alpha=.69, \beta=.17$ ), instrumental ("I like to be rewarded for extra responsibilities"; $\alpha=.77, \beta=.07$ ), self-concept external ("It is important that others appreciate the work I do"; $\alpha=.70, \beta=.05$ ), self-concept internal ("Decisions I make reflect my personal standards"; $\alpha=.70, \beta=.35$ ), and goal internalization ("I work hard for a company if I agree with its mission"; $\alpha=.77$, $\beta=.46$ )-achieved generally acceptable reliability estimates.

Locus of control was measured using three items from Rotter's measure (1966). The items included "I can control the things that happen in my life," "I can make a difference in most situations," and "The successes in my life result from my efforts." The three questions exceeded the accepted baseline value of .70 for reliability estimates $(\alpha=.71, \beta=.64)$. Questions were formatted in a 5-point Likert-type scale ranging from 0: Completely disagree to 4 : Completely agree.

Mental Boundaries were measured using the Boundary Questionnaire (Hartmann, 1991), a 6-item subscale for organizational and interpersonal boundaries. Reliability estimates for mental boundaries fell below the required value $(\alpha=.68, \beta=.52)$. Questions were formatted in a 5-point Likert-type scale ranging from 0: Completely disagree to 4: Completely agree.

Procedure

Data were collected from an intact group of elected officials as part of a full-day leadership-training seminar. Participants were members of an association which sponsors annual professional development programs for its members of which this research project was a part. Each participant was asked to distribute to all of their raters the raters' version of the LMX7. Raters completed their forms at the same time that leaders completed theirs. Test forms were coded in advance to protect the confidentiality of raters. Leaders' names were kept on a separate coding sheet for later interpretation and feedback during the leadership-development training program. The research was approved by the institutional review board and informed consent was achieved for all participants.

All questionnaires were returned directly to the first author via the U.S. Postal Service. Participants and their raters were provided letters detailing their participation and rights, which included withdrawal at any time during the research. None of the participants requested to be removed from the study. Because preregistration was used for elected officials, the response rate was high, as 80 of the eligible 92 elected officials participated.

\section{Results}

Means, standard deviations, and zero-order correlations were calcu- 
TABLE 1

Means, Standard Deviations, and Pearson Correlations $(N=388$

\begin{tabular}{|c|c|c|c|c|c|c|c|c|c|c|c|c|c|c|c|c|c|}
\hline \multirow[t]{2}{*}{ Variable } & \multirow[t]{2}{*}{$M$} & \multirow[t]{2}{*}{$S D$} & \multicolumn{15}{|c|}{ Correlations } \\
\hline & & & 1 & 2 & 3 & 4 & 5 & 6 & 7 & 8 & 9 & 10 & 11 & 12 & 13 & 14 & 15 \\
\hline 1. L-IP & 18.8 & 4.6 & .71 & & & & & & & & & & & & & & \\
\hline 2. L-Instr & 20.9 & 4.4 & $.34 \dagger$ & .78 & & & & & & & & & & & & & \\
\hline 3. L-SCE & 24.0 & 3.7 & $.31 \dagger$ & $.26 \dagger$ & .85 & & & & & & & & & & & & \\
\hline 4. L-SCI & 23.2 & 4.4 & $.36 \dagger$ & $.42 \dagger$ & $.55 \dagger$ & .82 & & & & & & & & & & & \\
\hline 5. L-Goal & 25.8 & 4.3 & $.14^{*}$ & $.30 \dagger$ & $.60 \dagger$ & $.58 \dagger$ & .73 & & & & & & & & & & \\
\hline 6. L-Loc & 8.6 & 1.8 & $-.11^{*}$ & $-.08^{*}$ & $.10^{*}$ & $.18 \dagger$ & .01 & .71 & & & & & & & & & \\
\hline 7. L-Bound & 15.2 & 2.7 & -.04 & .03 & -.01 & .03 & $.16^{*}$ & $.42 \dagger$ & .68 & & & & & & & & \\
\hline 8. F-IP & 19.3 & 5.9 & .04 & .01 & .05 & .01 & .02 & -.02 & .05 & .69 & & & & & & & \\
\hline 9. F-Instr & 21.2 & 5.9 & .05 & .06 & .05 & .06 & .03 & .06 & $.11^{*}$ & $.58 \dagger$ & .77 & & & & & & \\
\hline 10. F-SCE & 23.8 & 4.9 & .02 & .07 & .08 & .05 & .02 & .06 & .09 & $.53 \dagger$ & $.72 \dagger$ & .70 & & & & & \\
\hline 11. F-SCI & 24.1 & 5.2 & -.02 & -.01 & .06 & .03 & -.03 & .08 & $.12^{*}$ & $.45 \dagger$ & $.62 \dagger$ & $.71 \dagger$ & .70 & & & & \\
\hline 12. F-Goal & 25.5 & 5.2 & -.02 & -.06 & .05 & .02 & -.04 & .08 & $.14^{*}$ & $.42 \dagger$ & $.53 \dagger$ & $.68 \dagger$ & $.77 \dagger$ & $(.77)$ & & & \\
\hline 13. F-Loc & 8.4 & 1.8 & -.00 & -.03 & .03 & .06 & -.02 & .09 & .03 & .01 & -.00 & $.11^{*}$ & $.14^{*}$ & $.14^{*}$ & $(.71)$ & & \\
\hline 14. F-Bound & 15.4 & 3.1 & -.04 & $-.13^{*}$ & -.02 & -.01 & -.06 & .03 & .05 & .05 & .07 & .08 & $.11^{*}$ & .06 & $.14^{*}$ & $(.75)$ & \\
\hline 15. F-LMX & 22.1 & 4.9 & .03 & .00 & .08 & $.14^{*}$ & .04 & $.14^{*}$ & -.02 & .02 & -.02 & .09 & .06 & $.11^{*}$ & $.36 \dagger$ & .05 & (.89 \\
\hline
\end{tabular}

Note. - Coefficients alpha reported on the diagonal. L-IP = Leaders' Intrinsic Process; L-Instr $=$ Leaders' Instrumental; L-SCE = Leaders' Selfconcept External; L-SCI = Self-concept Internal; L-GOAL=Leaders' Goal Internalization; L-Loc=Leaders' Locus of Control; L-Bound=Leaders' Boundaries of the Mind; F-IP=Followers' Intrinsic Process; F-Instr=Followers' Instrumental; F-SCE=Followers' Self-concept External; F-SCI = Followers' Self-concept Internal; F-Goal=Followers' Goal Internalization; F-Loc=Followers' Locus of Control; F-Bound =Followers' Boundaries of the Mind; F-LMX = Followers' Ratings of their Leader-Member Exchange. ${ }^{*} p<.05 ; \dagger p<.003$ [because of the number of analyses, a Bonferroni adjustment $(15 \times .05=.003)]$. 
TABLE 2

Hierarchical Regression to Identify Best Predictive Model of Leader-Member Exchange

\begin{tabular}{lccccccc}
\hline \hline \multicolumn{1}{c}{ Model } & $R$ & $R^{2}$ & $R^{2}{ }_{\text {Adj. }}$ & $S E$ & $R^{2} \Delta$ & $F \Delta$ & $p$ \\
\hline 1. Followers' Locus of Control & .343 & .118 & .115 & .649 & .118 & 48.91 & $<.0001$ \\
2. Leaders' Self-concept Internal & .365 & .133 & .129 & .644 & .016 & 6.69 & .01 \\
\hline
\end{tabular}

Note.-Dependent Variable: Leader-Member Exchange (LMX). Variables not included: Leaders' Locus of Control, Followers' Goal Internalization. Model explains 13.3\% of the variance in Leader-Member Exchange.

lated for all variables examined in this study $\left(\mathrm{T}_{1}\right)$. From this analysis several significant values were found. A very small but significant relation was found between leaders' scores on internal locus of control and Leader-Member Exchange $\left(r=.14, p<.01 ; \mathrm{H}_{1}\right)$. A significant but very small relation was found between leaders' process on self-concept internal motivation and leader-member exchange $\left(r=.14, p<.01 ; \mathrm{H}_{6}\right)$. A significant correlation was obtained between followers' internal locus of control and Leader-Member Exchange quality $\left(r=.36, p<.01 ; \mathrm{H}_{10 \mathrm{a}}\right)$. There was also a weaker but significant correlation between followers' Goal-Internalization motivation and Leader-Member Exchange $(r=.11, p<.05)$, not hypothesized. Note values account for little common variance, reaching statistical significance because $N$ was very large.

No significant relations were found between leaders' thin mental boundaries $\left(\mathrm{H}_{2 \mathrm{a}}\right.$ and $\left.\mathrm{H}_{2 \mathrm{~b}}\right)$, intrinsic process motivation $\left(\mathrm{H}_{3}\right)$, instrumental motivation $\left(\mathrm{H}_{4}\right)$, self-concept external motivation $\left(\mathrm{H}_{5}\right)$, goal-internalization motivation $\left(\mathrm{H}_{7}\right)$, intrinsic-internal motivation $\left(\mathrm{H}_{8}\right)$, extrinsic or external motivation $\left(\mathrm{H}_{9}\right)$, or followers' thin mental boundaries $\left(\mathrm{H}_{10 \mathrm{~b}}\right)$, and leader-member exchange quality.

To test the best predictive model for the significant findings, the four variables were entered into a step-wise hierarchical model. The resulting model included followers' scores on locus of control and leaders' scores on self-concept internal motivation as independent variables and LeaderMember Exchange as the dependent variable $\left(\mathrm{T}_{2}\right)$. This model explained somewhat more than $13 \%$ of the common variance in the data $\left(r=.37 ; r^{2}=\right.$ $.13 ; r^{2}$ adj. $\left.=.13 ; S E=.64 ; F=.01\right)$. Although leaders' locus of control and followers' goal-internalization motivation shared statistically significant associations with Leader-Member Exchange, they did not contribute significantly beyond what was explained by followers' locus of control and leaders' self-concept internal motivation, but the overall amount left a substantial variance unaccounted for $(83 \%)$.

\section{DisCUSSION}

\section{Summary of Findings}

The most noteworthy findings of this study are the positive relations 
between followers' scores on locus of control and the quality of leadermember exchange. This relation accounted for $12 \%$ of the common variance in the data, from which one may infer that followers who believe they are in control of their destiny and outcomes will be more likely to develop constructive and positive relationships with their direct supervisors. This is noteworthy because the antecedents of leader-member exchange have been tested with a variety of variables in the past and these results compare favorably to other antecedents. Follower-centered variables were collected but not hypothesized in this sample, as attributes of leaders were the foci of the paper. The relationship between followers' scores of locus of control and the quality of leader-member exchange here may have been anticipated by some prior work linking locus of control with leader-member exchange (Gerstner \& Day, 1997; Howell \& Hall-Merenda, 1999). Also, the exclusion of work motivation and boundaries of the mind in the total variance accounted for indicates that the individuals' motives did not significantly affect the quality of the relations with direct supervisors.

A significant correlation (.36) between leaders' scores on self-concept internal motivation and leader-member exchange also is consistent with reports in previous literature that leaders with high scores on self-concept internal motivation tend to value individual members and their contributions. This would promote a positive leader-member exchange environment (Barbuto \& Scholl, 1999). A very small yet statistically significant correlation was found between followers' internal locus of control and leader-member exchange quality. Although not hypothesized, a weak but significant relation was found between followers' goal-internalization motivation and leader-member exchange. This suggests followers with high need to believe in the cause seem somewhat likely to develop strong and trusting relations with their direct supervisors.

\section{Limitations and Directions for Research}

The interpretations of present results are limited by the sampling procedures used in the study. However, all followers were asked to participate in the study-as opposed to more typical sampling procedures following which leaders hand select 4 to 6 raters to participate. Inviting participation from all dyadic followers reduced some of the sampling bias that would have been likely had leaders selected followers. Subsequent studies should also sample from as wide a target population as possible and remove leaders' discretion in the process.

The results of this study explained only $13 \%$ of the total variance in the data. Scholars are reminded that other variables not examined would be expected to yield significant explanation of leader-member exchange. A more comprehensive and inclusive predictive model may be useful to ascertain the best predictors of leader-member exchange across all poten- 
tial predictors. Testing other variables along with followers' locus of control would be useful, since the relations with leader-member exchange accounted for $12 \%$, and so $1 \%$ came from all other variables tested in this study. Single method variance seems likely to have inflated these relations. These results provide some information about the antecedents of leader-member exchange. Researchers may consider other dispositional variables of both leaders and followers when testing the predictors of leader-member exchange.

\section{REFERENCES}

Alderfer, C. P. (1969) An empirical test of a new theory of human needs. Organizational Behavior and Human Performance, 4, 142-175.

Avolio, B. J., Waldman, D. A., \& Einstein, W. O. (1988) Transformational leadership in a management game simulation. Group \& Organization Studies, 13, 59-79.

BARbuto, J. E. (1998) Motivation and leadership: towards a predictive model of leader influence behaviors. Dissertation Abstracts International, 58, 3202.

Barbuto, J. E. (2004) Motivation Sources Inventory. Lincoln, NE: Future Leadership.

Barbuto, J. E., Fritz, S. M., \& Marx, D. (2000) A field study of two measures of work motivation for predicting leaders' transformational behaviors. Psychological Reports, 86, 295-300.

Barbuto, J. E., Fritz, S. M., \& MARx, D. (2002) A field examination of two measures of work motivation for predicting leaders' influence tactics. Journal of Social Psychology, 142, 601-616.

Barbuto, J. E., \& Plummer, B. A. (1998) Mental boundaries as a new dimension of personality: a comparison of Hartmann's boundaries in the mind and Jung's psychological types. Journal of Social Behavior and Personality, 13, 421-436.

Barbuto, J. E., \& Scholl, R. W. (1998) Motivation Sources Inventory: development and validation of new scales to measure an integrative taxonomy of motivation. Psychological Reports, 82, 1011-1022.

Barbuto, J. E., \& Scholl, R. W. (1999) Leaders' motivation and perception of followers' motivation as predictors of influence tactics used. Psychological Reports, 84, 1087-1098.

BAss, B. M. (1985) Leadership and performance beyond expectations. New York: Free Press.

Bass, B. M. (1990) Bass and Stodgill's handbook of leadership. New York: Free Press.

Burns, J. M. (1978) Leadership. New York: Harper \& Row.

Burns, J. Z. (1995) Prediction of Leader-Member Exchange quality by Jungian personality type. Dissertation Abstracts International, 56, 1729.

Dansereau, F., Cashman, J., \& Graen, G. (1973) Instrumentality theory and equity theory as complementary approaches in predicting the relations of leadership and turnover among managers. Organizational Behavior and Human Performance, 10, 184-200.

DecI, E. L. (1975) Intrinsic motivation. New York: Plenum Press.

Deluga, R. J. (1992) The relationship with Leader-Member Exchange with laissezfaire, transactional, and transformational leadership in Naval environments. In K. E. Clark, M. B. Clark, \& D. P. Campbell (Eds.), Impact of leadership. Greensboro, NC: Center for Creative Leadership. Pp. 237-247. 
Dienesch, R. M., \& Liden, R. C. (1986) Leader-member exchange model of leadership: a critique and further development. Academy of Management Review, 11, 618-634.

Dockery, T. M., \& Steiner, D. D. (1990) The role of the initial interaction in leadermember exchange. Group \& Organization Studies, 15, 395-413.

FreUd, S. (1933) New introductory lectures on psychoanalysis. New York: Norton.

Gerstner, C. R., \& Day, D. V. (1997) Meta-analytic review of Leader-Member Exchange theory: correlates and construct issues. Journal of Applied Psychology, 82, 827-844.

Graen, G. B., Novak, M. A., \& Sommerkamp, P. (1982) The effects of Leader-Member Exchange and job design on productivity and satisfaction: testing an attachment model. Organizational Behavior and Human Performance, 30, 109-131.

Graen, G. B., \& Uhl-Bien, M. (1995) Relationship-based approach to leadership: development of Leader-Member Exchange (LMX) theory of leadership over 25 years: applying a multi-level multi-domain perspective. Leadership Quarterly, 6, 219-247.

Hartmann, E. (1991) Boundaries in the mind: a new psychology of personality. New York: HarperCollins.

Hartmann, E., Rosen, R., \& Rand, W. (1998) Personality and dreaming: boundary structure and dream content. Dreaming, 8, 31-39.

Hater, J. J., \& Bass, B. M. (1988) Superiors' evaluations and subordinates' perceptions of transformational and transactional leadership. Journal of Applied Psychology, 73, 695-702.

Hawk, S. R. (1989) Locus of control and computer attitude: the effect of user involvement. Computers in Human Behavior, 5, 199-206.

Herzberg, F. W. (1968) One more time, how do you motivate employees? Harvard Business Review, 46, 53-62.

Houran, J., Thalbourne, M. A., \& Hartmann, E. (2003) Comparison of two alternative measures of the boundary construct. Perceptual and Motor Skills, 96, 311-323.

Howell, J. M., \& Avolio, B. J. (1993) Transformational leadership, transactional leadership, locus of control, and support for innovation: key predictors of consolidated-business-unit performance. Journal of Applied Psychology, 78, 891-902.

Howell, J. M., \& Hall-Merenda, K. E. (1999) The ties that bind: the impact of LeaderMember Exchange, transformational and transactional leadership, and distance on predicting follower performance. Journal of Applied Psychology, 84, 680-694.

Johnson, A. L., Luthans, F., \& Hennessey, H. W. (1984) The role of locus of control in leader influence behavior. Personnel Psychology, 37, 61-75.

Jung, C. G. (1923/1971) Psychological types. In The collected works of C. G. Jung. Vol. 6. (R. F. C. Hull, Transl.) Princeton, NJ: Princeton Univer. Press.

Kinicki, A. J., \& Vecchio, R. P. (1994) Influences on the quality of supervisor-subordinate relations: the role of time-pressure, organizational commitment, and locus of control. Journal of Organizational Behavior, 15, 75-82.

Leonard, N. H., Beauvais, L. L., \& Scholl, R. W. (1999) Work motivation: the incorporation of self-concept-based processes. Human Relations, 52, 969-998.

Liden, R. C., Wayne, S. J., \& Stilwell, D. (1993) A longitudinal study on the early development of leader-member exchanges. Journal of Applied Psychology, 78, 662-674.

Locke, E. A., \& Henne, D. (1986) Work motivation theories. Chichester, UK: Wiley. 
Lord, R. G., DeVader, C. L., \& Alliger, G. M. (1986) A meta-analysis of the relation between personality traits and leadership: an application of validity generalization procedures. Journal of Applied Psychology, 71(3), 402-410.

Martin, R., Thomas, G., Charles, K., Epitropaki, O., \& McNamara, R. (2005) The role of leader member exchanges in mediating the relationship between locus of control and work reactions. Journal of Occupational and Organizational Psychology, 78, 141-147.

Maslow, A. (1954) Motivation and personality. New York: Harper \& Row.

McClane, W. E. (1991) The interaction of leader and member characteristics in the Leader-Member Exchange (LMX) model of leadership. Small Group Research, 22, 283-300.

McClelland, D. C. (1961) The achieving society. Princeton, NJ: Van Nostrand.

Nystrom, P. C. (1983) Managers' salaries and their beliefs about reinforcement control. Journal of Social Psychology, 120, 291-292.

Phares, E. J. (1973) Locus of control: a personality determinant of behavior. Morristown, NJ: General Learning.

Phillips, A. S., \& Bedeian, A. G. (1994) Leader-follower exchange quality: the role of personal and interpersonal attributes. Academy of Management Journal, 37, 9901001.

Revelle, W., \& Zinbarg, R. E. (2009) Coefficients alpha, beta, omega, and the GLB: comments on Sijtsma. Psychometrika, 74, 145-154.

Rotter, J. B. (1966) Generalized expectancies for internal versus external control of reinforcement. Psychological Monographs: General and Applied, 80, No. 1. (Whole No. 609), 1-28.

Spector, P. E. (1982) Behavior in organization as a function of employee's locus of control. Psychological Bulletin, 91, 482-497.

Staw, B. M. (1976) Knee-deep in the big muddy: a study of escalating commitment to a chosen course of action. Organizational Behavior and Human Performance, 16, 27-44.

Steiner, D. D., \& Dobbins, G. H. (1989) The role of work values in leaders' attributions and the development of leader-member exchanges. International Journal of Management, 6, 81-90.

Tsui, A. S., \& O’Reilly, C. A. (1989) Beyond simple demographic effects: the importance of relational demography in superior-subordinate dyads. Academy of Management Journal, 32, 402-423.

WAYNE, S. J., \& FerRIS, G. R. (1990) Influence tactics, affect, and exchange quality in supervisor subordinate interactions: a laboratory experiment and field study. Journal of Applied Psychology, 75, 487-499.

Wayne, S. J., Liden, R. C., \& Sparrowe, R. T. (1994) Developing leader-member exchanges: the influence of gender and ingratiation. American Behavioral Scientist, 37, 697-714.

Zinbarg, R.E., Revelle, W., Yovel, I., \& Li, W. (2005) Cronbach's $\alpha$, Revelle's $\beta$, and McDonald's $\omega_{\mathrm{H}}$ : their relations with each other and two alternative conceptualizations of reliability. Psychometrika, 70, 123-133. 